\title{
The Effect of Anchovy Stolephorus baganensis on Salivary Mutans Streptococci
}

\author{
Harun Agunawan \\ Soeherwin Mangundjaja \\ Department of Oral Biology Faculty of Dentistry, Universitas Indonesia \\ Jakarta, Indonesia \\ E-mail:erwin@ui.ac.id \\ Received August 15, 2010; Accepted September 16, 2010
}

\begin{abstract}
A clinical trial was carried out to investigate the effect of Anchovy of Stolephorus baganensis on mutans streptococci inhibiting the growth of the salivary mutans streptococci for a period of one week consumption. Before enrolled in the study, respondents filled out and signed the informed consent. Twenty respondents participated as the subjects on the clinical trial, conducting two times of treatment as follows: twenty as treatment groups before and after consuming anchovy of Stolephorus baganensis and the twenty subjects as control groups before and after consuming non-anchovy of Stolephorus baganensis. Saliva samples were collected before and after consuming anchovy of Stolephorus baganensis and with a non-anchovy of Stolephorus baganensis. A serial dilution was made, followed by inoculating on TYS20B medium). Data which were obtained from colony forming units of salivary mutans streptococci grew on the TYS20B medium before and after consuming anchovy of Stolephorus baganensis were analyzed in a descriptive and " $\mathrm{t}$ " test. Results showed that there was no significance in the average amount of Streptococcus mutans colonies between before and after consuming non-anchovy of Stolephorus baganensis. However, a significant difference was found respectively as results before and after consuming anchovy of Stolephorus baganensis. We concluded that Anchovy of Stolephorus baganensis has antimicrobial activity against local strains of Streptococcus mutans isolated from human harboring species. Therefore in a long term of consuming Anchovy fish of Stolephorus baganensis, caries can be prevented
\end{abstract}

Keywords: Anchovy of Stolephorus baganensis, Salivary Mutans Streptococci.

\section{Introduction}

Streptococcus mutans harbored in the dental plaque is thought to be the main agent to caries prevalence. Acidogenicity and aciduricity are important biochemical characteristics for cariogenicity of microorganisms. The mutans streptococci have both of these properties and considered the most cariogenic group within the oral micro flora. ${ }^{1.2}$

For this reason early prevention is needed to maintain the oral health by rinsing with mouthwash and tooth brushing as it is the most widely used and socially accepted form of oral hygiene. ${ }^{3}$ Mouth rinsing and tooth brushing are the principal way for mechanical removal of plaque and to prevent Streptococcus mutans colonized in teeth. ${ }^{3.4}$

Anchovy fish of Stolephorus baganensis contains nutritional contents of carbohydrates, proteins, fats, vitamins, and minerals. One of the important nutritional elements in Anchovy fish is the fluoride. The fluoride level in this fish is quite high ranging from 5 to $35 \mathrm{ppm}$, thereby anticipating that oral health is maintained by regularly consuming Anchovy fish ${ }^{5}$. 
This research is expected to contribute significantly to the world of science that Anchovy substrate of Stolephorus baganensis can inhibit the bacterial growth of mutans of Streptococci mutans, therefore in a long term of consuming Anchovy fish of Stolephorus baganensis, caries can be prevented.

\section{Materials and Methods}

The material used in this study is a substrate substance from Stolephorus baganensis. The bacteria used as analysis unit was salivary mutans streptococci. TYS20B medium (Shaeken,M.J.M , van der Hoeven, J.S and Franken, H.C.M , 1986) ${ }^{6}$ for the growth of Streptococcus mutans.

Twenty respondents were participated as research subject: 20 subjects treated two times with consuming Anchovy of Stolephorus baganensis and with consuming non-anchovy of Stolephorus as control group.

\subsection{Data collection}

The data collection mechanism was as follows:

1. Respondents filled and signed the informed consent.

2. Before and after consuming non-anchovy of Stolephorus baganensis and anchovy of Stolephorus baganensis, respondents chew sterile paraffin to obtain considerable amount of saliva and the saliva was collected. Two hours after consuming anchovy, saliva were collected.

3. Saliva samples was then used for a serial dilution

4. $1 \mathrm{ml}$ of saliva was diluted with $9 \mathrm{ml}$ sterile saline to make a serial dilution and from the tube of 1000 fold dilution, was then taken $0.1 \mathrm{ml}$ of solution to inoculate in the selective medium of TYS20B (Schaken et al, 1986)

5. All samples were incubated in anaerobic jar at temperature of $37^{\circ}$ Celsius for $3 \times 24$ hours.

6. Subjects were treated with consuming anchovy of Stolephorus baganensis and non-anchovy of Stolephorus baganensis, $3 \times 25$ gram anchovy daily for a period of one week consumption.
7. The Colony Forming Units (CFU) of Streptococcus mutans which grew in the TYS20B medium were then counted and recorded.

\subsection{Statistical analysis}

Data obtained from colony forming units of salivary mutans streptococci grew in TYS20B medium before and after treatment were analyzed in a descriptive method and " $\mathrm{t}$ " test.

\section{Results}

The results of analyzed colony forming units (CFU) amount of Streptococcus mutans which grew on TYS20B media before and after consuming with anchovy and non-anchovy of Stolephorus baganensis are shown on Table 1.

Table 1. Mean and Standard Deviation (SD) of CFU Streptococcus mutans on treatment with anchovy and non-anchovy of Stolephorus baganensis.

\begin{tabular}{lrr}
\hline \multicolumn{1}{c}{$\mathrm{N}=20$} & Mean & SD \\
\hline Before - non anchovy & 410.50 & 234.90 \\
After - non anchovy & 387.00 & 326.12 \\
Before - anchovy & 381.75 & 315.91 \\
After - anchovy & 84.25 & 80.08 \\
\hline
\end{tabular}

Table 1 shows that Colony Forming Units of Streptococcus mutans after consuming with anchovy of Stolephorus baganensis. $(\mathrm{X}=84.25+/-\mathrm{SD}=80.08)$ was lower than before consuming anchovy of Stolephorus baganensis. ( $\mathrm{X}=381.75+/-\mathrm{SD}=315.91)$. The Colony Forming Units of Streptococcus mutans after consuming anchovy of Stolephorus baganensis $(\mathrm{X}=84.25+/-\mathrm{SD}=80.08)$ was also lower than after consuming non - anchovy of Stolephorus baganensis $(X=387.00+/-S D=326.12)$.

The significance of the effectiveness of anchovy of Stolephorus baganensis, a " $\mathrm{t}$ " test analysis was done and the results can be seen on Table 2 . Significant level was accepted when p-level at $5 \%$ was lower than $0.05(p<0.05)$. 
Table 2. " $\mathrm{t}$ " test on treatment with anchovy and non-anchovy of Stolephorus baganensis.

\begin{tabular}{lrrrrr}
\hline $\begin{array}{l}\text { Difference of } \\
\text { Treatment }\end{array}$ & Df & $\mathbf{t}$ & $\mathbf{p}$ & Significance \\
\hline $\begin{array}{l}\text { Before-After Consuming } \\
\text { (non-anchovy) }\end{array}$ & 18 & 0.285 & 0.946 & $\mathrm{P}<0.05$ \\
$\begin{array}{l}\text { Before-After Consuming } \\
\text { (anchovy) }\end{array}$ & 18 & 3.560 & 0.005 & $\mathrm{P}<0.05$ \\
$\begin{array}{l}\text { Before chewing } \\
\text { (non-anchovy-anchovy) }\end{array}$ & 18 & 0.440 & 0.800 & $\mathrm{P}<0.05$ \\
$\begin{array}{l}\text { After chewing } \\
\text { (non-anchovy -anchovy) }\end{array}$ & 18 & 2.780 & 0.010 & $\mathrm{P}<0.05$ \\
\hline
\end{tabular}

No significant difference was found between the Colony Forming Units of Streptococcus mutans before and after consuming non-anchovy of Stolephorus baganensis, where p-level at $5 \%$ was 0.946 and t-value was 0.295 .

As expected, the amount of Colony Forming Units salivary mutans streptococci showed very significant difference of the Colony Forming Units of Streptococcus mutans before and after consuming anchovy of Stolephorus baganensis, where p-level at $5 \%$ was 3.560 and t-value was 0.005 . When Colony Forming Units of Streptococcus mutans before and after consuming non-anchovy of Stolephorus baganensis was compared with the group consuming anchovy of Stolephorus baganensis, the t-value 0.440 where $p$-level at $5 \%$ was 0.800 meaning that there was no significant difference.

The group after consuming non - anchovy of Stolephorus baganensis was compared with after consuming anchovy of Stoleophorus baganensis, it was shown significant difference ( $\mathrm{t}$-value was 2.780 where $p$-level at $5 \%$ was 0.010 ).

\section{Discussion}

The results on Table 1 shows that the amount of Colony Forming Units of Streptococcus mutans after consuming anchovy of Stolephorus baganensis was lower than the amount of Colony Forming Units of
Streptococcus mutans after consuming non anchovy of Stolephorus baganensis..

After consuming non-anchovy of Stolephorus baganensis the Colony Forming Units of Streptococcus mutans decreased, in comparison with the Colony Forming Units of Streptococcus mutans before consuming non - anchovy of Stolephorus baganensis.

The results on Table 2 shows that there was highly significance difference in the average amount of Streptococcus mutans colonies between before and after consuming anchovy of Stolephorus baganensis.

In the previous study it has been proven that Anchovy substrate of Stolephorus baganensis has anti microbial activity against standard strains of Streptococcus mutans $L M 7$, Streptococcus mutans JC 2 , Streptococcus mutans KPSK2, Streptococcus mutans Ing Britt, and Sreptococcus sobrinus B13 ${ }^{7}$ and local strains of mutans of Streptococcus mutans isolated from human harboring species ${ }^{8}$.

In Indonesia, dental caries is still a big problem in the dentistry, although efforts to overcome it has been made, such as by using fluoridation method, which can be systemic or topical application.

However considering the very small need of systemic fluoride by human beings, i.e about 1.7$3.3 \mathrm{ppm}$ daily, it is very difficult to determine the concentration of ionic fluoride which should be given to the people, because of the harmful side effect of systemic fluoride administration so this method is already left out.

So we carried out another method of topical fluoridation among others by chewing food, before it swallowed, which is rich in fluoride, i.e. anchovy Stolephorus baganensis that has fluoride property of about $5-18 \mathrm{ppm}^{5}$.

\section{Conclusion}

The research showed that anchovy Stolephorus baganensis has bactericide activity on mutans of Streptococcus mutans. Anchovy of Stolephorus baganensis is traditional food for the population along the coast of Indonesia.

Because anchovy of Stolephorus baganensis contains high fluoride ion, it also can be used as a 
topical application. In this point, early risk of caries can be anticipated and prevented, by a long term consumption of Anchovy fish of Stolephorus baganensis.

\section{Acknowledgment}

We would like to thank Directorate for General Affair Facilities, Universitas Indonesia which has supported this research.

\section{References}

1. Bratthall D. 1970. Demonstration of five serological groups of streptococcal strains resembling Streptococcus mutans. Odontol Revy 21: 143-152.

2. Emilson CG, Lindquist B, Krasse B. 1989. Colonization pattern of two serotypes of mutans streptococci implanted in human. Caries Res 23: 94.

3. Newbrun E. 1989. Cariology $3^{\text {th }}$ ed Quentessence Publishing Co. Inc : 148-50.

4. Erickson L. 1997. Oral health promotion and prevention for older adult. J Dent Clinics of North America 41 (4): 731.
5. Ayu Wulandary, Harun A Gunawan. 2004. The Analysis Of Fluoride Compound In Dried Anchovy and in The Enamel After Application with Commersons Anchovy Substrate. Dissertation of the Faculty of Dentistry University of Indonesia.

6. Schaeken MJM, Van der Hoeven JS, Franken HCM. 1986. Comparative recovery of Streptococcus mutans on five isolation media including a new simple selective medium. J Dent Res 65: 906-8.

7. Mangunjaja S, Yuni A, Andy S. 2005. In vitro anti microbial activity of anchovy substrate of Stolephorus commersonii on mutans streptococci. Paper read at the International Meeting on Dentistry for the Nano-InformaticGenomic-Technology Era and The $7^{\text {th }}$ Thai Dental Faculties Board Scientific Meeting. February 24, 2005 Sofitel Raja Orchid, Khon Kaen Thailand.

8. Soekanto SA and Mangundjaja S. 2005. Effect of anchovy substrate of stolephorus commersonii on mutans of streptococcus mutans isolated from human harboring species in Bangka Island indonesia. Paper read at the $4^{\text {th }}$ Indonesian Association for Pediatric Dentistry Meeting 8 9 April, 2005 at University of Pajajaran Bandung Indonesia. 